\title{
MUSIC-MAKERS AND REFORMED THEOLOGY
}

\author{
Jahdiel N. Perez \\ Mahasiswa Filsafat dan Teologi Kristen, Harvard Divinity School
}

\begin{abstract}
ABSTRAK: Apabila teologi Reformed diharapkan sebanyak mungkin berdampak kepada masyarakat masa kini dan masa depan, keunikan dari kekuatan musik untuk mempengaruhi dunia di luar tembok Gereja haruslah diberdayakan. Di dalam esai ini, penulis ingin menunjukkan bagaimana kekristenan, secara umum, dan teologi Reformed, secara khusus, dikritik melalui musik dan apa yang dapat kita lakukan untuk merespons. Penulis akan memperkenalkan sebuah pendekatan di dalam apologetika Kristen yang disebut sonic-apologetics yang memampukan para pembuat musik untuk mempertahankan iman melalui musik. Di dalam bagian pertama dari esai ini, penulis akan mendiskusikan lima masalah dan bagaimana sonicapologetics menjawab. Ini yang kemudian akan menjadi dasar untuk bagian kedua dari esai ini, yaitu penulis akan membangun sonic-apologetics dari tiga gagasan: (1) penekanan metodologis dari efek, (2) genre dari ekspresi, dan (3) perbedaan antara respons apologetika linear dan angle. Di dalam bagian terakhir dari esai ini, penulis akan memaparkan dua studi kasus yang berbeda dari sonic-apologetics. Sonic-apologetics yang didiskusikan di sini tidak akan mengubah aturan liturgika yang sudah terdapat pada gerejagereja Kristen, terutama yang Reformed. Tetapi sonic-apologetics mengajak para produser dan pemusik di dalam gereja-gereja ini untuk mengarahkan minat dan kemampuannya untuk membuat musik kepada dunia di luar tembok gereja.
\end{abstract}

KATA KUNCI: teologi reformed, musik, sonic-apologetics. 
ABSTRACT: If Reformed theology hopes to impact contemporary and future societies as much as possible it will have to harness the unique power of music to influence the world beyond the walls of the Church. In this essay, I want to draw attention to the ways in which Christianity, in general, and Reformed theology, in particular, are criticized through music and what we can do to respond. I will introduce an approach to Christian apologetics, which I call sonic-apologetics that enables our music-makers to defend the faith musically. In the first part of this paper, I will discuss five problems to which sonic-apologetics is an answer. This will anchor the second part of this essay, in which I construct sonic-apologetics from three notions: (1) methodological emphasis on effects, (2) genres of expression, and (3) the distinction between linear and angled apologetic responses. In the final part of this essay, I present two different study cases of sonic-apologetics. Nothing about what I will discuss regarding sonic-apologetics changing existing liturgical norms of Christian churches, especially Reformed ones. It does, however, call for those producing and performing music in these churches to direct their music-making interests and abilities toward the world outside the church walls.

KEYWORDS: reformed theoplogy, music, sonic-apologetics.

\section{Introduction}

If Reformed theology hopes to impact contemporary and future societies as much as possible it will have to harness the unique power of music to influence the world beyond the walls of the Church. This is much easier said than done, especially because for centuries the Church has directed its music inward and used it for liturgical purposes without caring to aim it outward for the sake of impacting the society surrounding it. Unlike the $16^{\text {th }}$ century Reformers, the world we today seek to impact is not just religiously 
and theologically hostile to Reformed truth but also philosophically, scientifically, and musically inimical to it as well. Since we find ourselves critiqued on many fronts, God's call to impact society is also a call to engage in apologetics. Reformed theology must not only be persuasively communicated to the world but also defended from its various cultural critics and social opponents therein.

In this essay, I want to draw attention to the ways in which Christianity, in general, and Reformed theology, in particular, are criticized through music and what we can do to respond. I will introduce an approach to Christian apologetics, which I call sonic-apologetics, that enables our musicmakers to defend the faith musically. This will foreground music as a valuable resource for and powerful instrument of apologetics. In the first part of this paper, I will discuss five problems to which sonic-apologetics is an answer. This will anchor the second part of this essay, in which I construct sonic-apologetics from three notions. In the final part of this essay, I present two different cases of sonic-apologetics, one coming from Amanda Cook's 2015 contemporary worship song "Kind" and the other from Michael Tait's 2011 pop rock song "God's Not Dead." Nothing about what I will discuss regarding sonic-apologetics changing existing liturgical norms of Christian churches, especially Reformed ones. It does, however, call for those producing and performing music in these churches to direct their musicmaking interests and abilities toward the world outside the Church walls. Sonic-apologetics is essentially aimed toward society, not the sanctuary; it is an apologetic and musical response triggered by various types of cultural criticisms of Christianity.

\section{Five Challenges That Sonic Apologetics Meets}

The need for sonic-apologetics will not be properly felt and appreciated until we understand the problems to which it is an answer. In 
other words, sonic-apologetics will seem superfluous until we see the significant challenges confronting Reformed theology and apologetics that it proposes to meet. There are at least five such challenges.

1. Apologetics has neglected music as a valuable and powerful (re)source available to its service. The task of apologetics is to persuasively communicate and defend the Gospel of Jesus Christ. In doing so, it should utilize all the best resources available for doing so. Music is a powerful means of persuasion. It can form and foster certain worldviews while criticizing others. Not all persuasion is by means of rational argumentation. By "persuasion" I understand anything that can move you, consciously or subconsciously, to accept, affirm or reaffirm views or values as worthy of assent or action. According to this broad definition, music has always been a unique source and instrument of persuasion. The founders of Reformed theology knew this well.

In his Forward to Georg Rhau's 1538 Symphoniae, Luther writes, "In summa, next to the Word of God, the noble art of music is the greatest treasure in the world. It controls our thoughts, minds, hearts, and spirits..." 1 This power to control heads and hearts is included in what I mean by persuasion. The sounds of music, as Luther heard them, were comparable in power to the words of theology. Where the ink of theology appeals solely to the mind, the melodies of music could influence the rational and nonrational aspects of us. It has power to persuade that theology, by itself, cannot match.

Calvin corroborates this in his Principle Genevan Psalter, where he writes, "there is scarcely in the world anything which is more able to turn or

\footnotetext{
1 As quoted in John Barber, "Luther and Calvin on Music and Worship," Reformed Perspectives Magazine (June 25, 2006),

http://www.thirdmill.org/newfiles/joh_barber/PT.joh_barber.Luther.Calvin.Music.Worship.pdf (accessed March 3, 2016).
} 
bend this way and that the morals of men [than music]... We find by experience that it has a sacred and almost incredible power to move hearts in one way or another." 2 Calvin observed that music has an unparalleled power to influence moral attitudes, desires, and behaviors. He calls music's power to move human hearts "sacred" and "almost incredible." The morality of a people and the heart of an individual person are both shaped by the power of music, for Calvin. This too is included in what I mean by music's persuasive power.

How does music have this power? Calvin's response is in terms of subject matter (the letter) and melody (the song). The tunes of the latter portray the text of the former. Again in the Principle Genevan Psalter he states, "when the melody is with [the message], it pierces the heart much more strongly, and enters into it; in a like manner as through a funnel, the wine is poured into the vessel [of the heart]."3 In Calvin's mind, music is a unique instrument for proclaiming a message. When the text or subject matter of this message is clothed in melodies and tunes it pierces the heart more directly and immediately than it could otherwise. This means that music has a unique power to touch the heart and persuade it in ways that the texts of theology, philosophy, science and literature do not. As such, apologetics can and should use music for apologetic purposes, if it wants to use all its available resources, not to mention the best ones.

The problem is that music has virtually never been regarded as a (re)source for apologetics, compared to theology, philosophy, science, and literature. Although Calvin and Luther held it had power to persuade that these intellectual disciplines did not, we have neglected music in favor of them as (re)source for apologetics. This is due mostly to the fact that apologetics is a sub-discipline of theology. A cursory glance at the textbooks

Ibid.

3 Ibid. 
testifies that music has not been among the four traditional resources of Christian theology: Scripture, reason, experience, and tradition. ${ }^{4}$ This challenge intensifies with Reformed theology's emphasis on sola scriptura, since it submits all other theological (re)sources, which does not even include music, to the authority of Scripture. The first problem, then, is that music has the kind of power to persuade that apologetics wants and needs but has neglected for centuries. Sonic-apologetics begins to turn this tide by harnessing the power of music as an indispensible instrument for Christian apologetics and Reformed theology.

2. In endeavoring to impact culture, apologetics ought to respond to all criticisms and objections to Christianity. Music, as we will see below, has functioned as a way to criticize Christianity. As such, apologetics ought to respond to those producing and performing these kinds of musical criticisms of the Gospel. Said differently, apologetics should defend the faith from anything trying to keep people away from it. Music has been used to keep its audience away from the faith. Therefore, apologetics ought to respond to this kind of music. But, most apologists do not care about popular music or deem musicians as worthy adversaries compared to philosophers, theologians, scientists or non-Christian religious scholars. Apologists have cared about anti-Christian books and lectures but not antiChristian songs, songwriters, and music-makers. Without attending to musical criticisms of the Gospel, the task of apologetics is pursued only partially and incompletely. Sonic-apologetics enables Christian apologetics to respond to musical criticisms of Christianity. As such, it enables apologetics to pursue its task more completely than it could otherwise.

\footnotetext{
4 See Alister E. McGrath, "The Sources of Theology," Christian Theology: An Introduction, 5th ed. (Chichester, West Sussex, U.K.: Wiley-Blackwell, 2011), 120-50. With Don Saliers' 1994 Worship as Theology, which argues that "worship in all its social-cultural idioms is a theological act," there is a move towards making worship a primary source for theology. See Don E. Saliers, Worship As Theology: Foretaste Of Glory Divine (Nashville: Abingdon Press, 1994).
} 
3. The need for democratization in apologetics is the third problem to which sonic-apologetics offers an answer. At its best, apologetics is an instrument of evangelism. It is meant to bring people to Christ and Christ to people. Like evangelism, apologetics is a task given to the entire body of Christ. Similar to Luther's "priesthood of all believers," there should be, so to speak, an "apologisthood of all believers."

Evangelism is the kind of endeavor anyone in the Church can do, regardless of their interest in logic, science or literature. Apologetics should be the same way. It should be the sort of thing anyone in the Church can participate in regardless of their investment in theology, philosophy or science. In other words, the commission in 1 Peter 3:15, to "give an answer to everyone who asks you to give the reason for the hope within you," is addressed to all Christians not just those who are drawn to logic, theology, philosophy, or science. To "contend for the faith," as Jude 1:3 puts it, is as much a task given to the singers and musicians of our churches as it is to the Biblical scholars therein.

The problem is that apologetics has become contingent and centered on a particular set of intellectual interests and abilities. If you do not have these intellectual interests and abilities than you are not fit for or called to apologetics. This is why our music-makers do not feel or regard themselves as called to apologetics. Apologetics should make itself accessible and tailor itself to the interests and abilities of non-traditional-apologists, like musicians and music-makers. Sonic-apologetics does just that.

4. Apologetics is part of a broader God-given endeavor to impact our surrounding societies and cultures with the Gospel of Jesus Christ. Music has an unparalleled power to influence societies and cultures on many levels. Plato, in his Republic, writes that "a change to a new type of music is something to beware of as a hazard of all our fortunes. For the modes of 
music are never disturbed without unsettling of the most fundamental political and social conventions. ${ }^{5}$ In other words, music is tightly linked to vital sociopolitical norms. To change musical norms, for Plato, is to threaten to change the most fundamental social conventions. Related to this is Calvin's view that that music can shape not just the collective morality of a people but also the individual heart of a person.

No wonder, then, why the $17^{\text {th }}$ century Scottish Politician Andrew Fletcher famously said, "Let me write the songs of a nation; I care not who makes its laws." "This is a bold statement, especially from such an able politician as Fletcher. Yet he recognized that songwriters could shape a society more than lawmakers like himself.

This sentiment is anthropologically applied in John Blacking's 1970 lectures titled How Musical Is Man?, where he observes how music, society, and culture interrelate, especially within the South African Venda peoples. He observed that there are "structural relationships between music and social life."7 Blacking defines music as "humanly organized sounds." He observes that the patterns by which sounds are humanly organized in a society mirror the patterns of human organization in that society. Said differently, the social relationships that form the horizon of our daily experiences mirror relationships in the production of music. Similar to Plato's insight, Blacking observes that when there is a change in the way social relationships are organized there is usually also a change in the organization of music. Therefore, music not only reflects sociocultural values and political situations but it also has the power to provoke new ones as well.

\footnotetext{
5 Plato, The Republic, 424c.

6 For the importance of songs in Andrew Fletcher's political thought, see P. H. Scott, The Saltoun Papers: Reflections on Andrew Fletcher (Edinburgh: Saltire Society, 2003), 60-75,125-188. 7 John Blacking, How Musical Is Man? (Seattle: University of Washington Press, 1973), 53.
} 
Given music's unique power to significantly shape key aspects of society, apologetics ought to use this power in working to impact culture with the Gospel. But, as we have seen, music has been historically disqualified from being a valuable resource for apologetics. This is the fourth challenge to which sonic-apologetics offers an answer.

5. We are being slaughtered on the sound waves. This is the final and most urgent challenge confronting Reformed theology, in particular, and Christianity, in general. Given the massive and unmatched power to persuade individuals and significantly influence cultures, how are we using music? Christianity's critics have weaponized the power of music and effectively wielded it against us. In doing so, there is an unintended coordination between anti-Christian intellectuals and anti-Christian musicmakers. The former assaults the mind while the latter attacks the head and the heart. Here are two examples, among thousands, from very different genres.

In 2011, Drake produced a rap song called "The Motto," which has over 50 million views on YouTube. The song urges its audience to live sinfully and licentiously because there is no afterlife; all we have is the here and now. This is why his motto is "YOLO" (You Only Live Once). This motto gained massive cultural influence in the United States in 2011. From T.V. personalities to kids on the street, it seemed as if almost everyone was using the motto to justify utterly ungodly actions. Go out partying, you only live once; smoke the blunt, you only live once; sleep with the girl, you only live once. Not only did the song contradict Reformed theology about life and the afterlife, but it also urged listeners to embody this contradiction by living in rebellion to Christianity. This song asserts implications of atheistic materialism and naturalism, namely that this physical life is all we have; there are no eternal consequences to our actions because we have no souls that live beyond death; there is no human accountability to God. This is the atheistic message which the melody of the song carries directly into the head 
and heart as through a funnel. This song is engineered to have sinful, idolatrous, and anti-Christian effects in society. As such, it is a musical criticism of Christianity.

In a much different genre, the Irish musician Hozier released a song titled "Take me to Church" in 2014 that won a 2015 Grammy for Best Song of the Year. It currently has close to 400 million views on YouTube. Here are some of the lyrics.

Every Sunday's getting more bleak

A fresh poison each week

'We were born sick, ' you heard them say it

My church offers no absolutes

She tells me 'worship in the bedroom'

I was born sick, but I love it

Command me to be well

Amen. Amen. Amen.

Take me to church

I'll worship like a dog at the shrine of your lies

I'll tell you my sins and you can sharpen your knife

Offer me that deathless death

Good God, let me give you my life.

This is another musical criticism of Christianity. First, it asserts that Churches are places where poisons are served from the lips of pastors. Calvin's doctrine of total depravity is one such poison, which you hear the pastors preach. The fourth line critiques the notion of absolute truth in favor of relativism. Then the song exalts sex in the bedroom as the proper object of worship, not God. The next line urges its audience to lovingly embrace the sickness which Christianity calls sin. "I was born sick, but I love it." The first 
two lines of the chorus, which starts with "Take me to church," asserts that church is a place where people worship lies like dogs. The last three lines critique the practice of confession. This song uses Christian language and imagery to subvert Reformed views and values. And it does this more effectively than can anti-Christian philosophical, theological, or scientific texts expressing the same messages.

Everyday the cultural despisers of Christianity are mass-producing these kinds of songs and circulating them in society. These build cultural barriers to the reception of the Gospel. Every anti-Christian sentiment expressed in a popular song, no matter the genre, is a seed planted in the cultural soil of our society that can grow roots of resistance to Reformed theology. The unique powers of music have been turned against the Church. Meanwhile, the Church has directed its music-making abilities inward for the sake of liturgical purposes without caring to aim it outward to society. In the process, there is no teamwork between our Christian musicians, which do one thing, and our intellectuals, which do a wholly disparate other. We are fixed on and content with wining one soul at a time while the Enemy aims at taking over institutions like music that affect millions and millions of people. This is why I mention the amount of view on YouTube these songs have gotten.

We can no longer afford to let these musical criticisms of Christianity go unanswered. We can no longer afford to let the ungodly world hijack music and monopolize its power against us. To impact current and future cultures as much as possible, Reformed theology will have to defend itself not just from theological, philosophical, and scientific critiques but against musical ones as well. This is where sonic-apologists come in. 


\section{Constructing Sonic-Apologetics}

There are three notions I take as necessary for constructing sonicapologetics, which also also respond to the five mentioned challenges confronting Reformed theology. The first is a methodological emphasis on effects, with a hint of hermeneutical suspicion. This comes close to what Walter Mignolo calls the geopolitics of knowledge production, which is an approach to knowledge guided by questions like, "Who and when, why and where is knowledge generated...? Asking these questions means to shift the attention from the enunciated to the enunciation." 8 Rather than seeking an analysis of the content of knowledge and truth claims, this methodological orientation treats them as items produced for certain purposes. There is hermeneutical suspicion here because the purposes to which knowledge and truth claims are produced are never naïve, neutral or what they seem to be; there are always ulterior motives operating, often times concealed from the speaker himself. Inspired by Foucault and Nietzsche before him, Mignolo consistently views the purposes behind the production of knowledges as steeped in power politics. For him, knowledge, science, and truth are produced to meet the hegemonic needs and interests of systems of power that oppress colonized peoples.

The enunciated/enunciation distinction Mignolo makes is key here. This epistemological approach attends to the effects that knowledge and truth claims produce rather than their propositional content. Instead of asking "is x true?", Mignolo's approach asks, "who wants me to believe that $\mathrm{x}$ is true?", "what are the effects of believing $\mathrm{x}$ is true?", "where is power taken and given in believing that $\mathrm{x}$ is true?", "who gets to say that $\mathrm{x}$ is true and who does not?" and "what needs are met and interests advanced in

\footnotetext{
8 Walter Mignolo, Theory, Culture \& Society 26 no. 7-8 (SAGE, Los Angeles, London, New Delhi, and Singapore, 2009): 1-23. DOI: 10.1177/0263276409349275.
} 
believing that $\mathrm{x}$ is true?" Focusing on the saying of something as opposed to what is said allows Mignolo to call attention to exactly what needs to be attended to in order to be epistemically disobedient, which for him is the first step towards decolonization, which is his objective.

Christian apologetics has seldom taken this kind of approach to knowledge, perhaps because it smacks of postmodernism. We normally inquire into the content of knowledge and truth claims - their validity, soundness, coherence, and relevance - but never treat them as produced, motivated, and circulated with specific anti-Christian purposes. There are, however, numerous advantages and strategic benefits for doing so. Said differently, Mignolo's objective is not our goal as Christians, but adopting his kind of approach offers the types of benefits we need to construct sonicapologetics. Sonic-apologetics is made possible by paying methodological attention to what someone is trying to do when they criticize Christianity and less to what they are trying to say. This means prioritizing effects of enunciation over content enunciated.

It serves our purposes efficiently to identify two fundamental types of effects of enunciation in the field of apologetics. I take a page from C.S. Lewis' Screwtape Letters here, where the elder demon says, "It does not matter how small the sins are provided that their cumulative effect is to edge the man away from the Light and out into the Nothing." ${ }^{\prime 9}$ In the context of apologetics, the effects of a particular knowledge or truth claim can either edge someone closer to God and the Gospel or further away from them into darkness, the Enemy and the Nothing. Those are the two categories we should have at hand when interpreting the effects of enunciating an argument, premise, knowledge or truth claim in the field of apologetics. Everything else is secondary and less significant. What is essential is

\footnotetext{
9 C. S. Lewis, The Screwtape Letters: With, Screwtape Proposes a Toast (San Francisco: HarperSanFrancisco (1942), 2001), 60, emphasis added.
} 
whether this particular premise or assertion, this argument, this set of claims gets its audience closer to or further away from God. On these grounds, we can begin to argue that music can have the same effect as a well-formed rational argument but through different (more efficient) means i.e. to edge or keep someone closer to or further away from God.

Now, knowledge and truth claims can be made (enunciated) in a variety of ways. There are many means available to humans in order to express, for instance, that 'God does not exist' or that 'God is not good.' The second notion necessary for framing sonic-apologetics, which I call genres of expression, picks this out. By this phrase I mean to signal the variety of ways available for humans to express knowledge and truth claims about reality. Theology, philosophy, the sciences, textbooks, novels, poems, dramas, narratives, fiction, prose, propositions, film, architecture, sermons, prayers, performative arts, visual arts, songs, and lyrics are some of the ways knowledge and truth claims come to be variously asserted and expressed in a culture. Each particular one hopes to say something about reality but also do something to its audience in the process. It is only through these genres of expression that knowledge and truth claims can produce effects on people and have any cultural influence at all.

By genres of expression, I do not mean to imply a mere classification, as the word "genre" functions in literary criticism and music. I do mean something similar to how Paul Ricoeur uses his expression "modes of discourse," which for him refers to the "narratives, prophecies, legislative texts, proverbs and wisdom sayings, hymns, prayers, and liturgical formulas" in the Bible. ${ }^{10}$ Modes of discourse, for Ricoeur, produce religious language in the Bible and not just merely classify it there. "In the same way,"

\footnotetext{
10 Paul Ricoeur, "Philosophy and Religious Language" [1974] in Figuring the Sacred: Religion, Narrative, and Imagination, edited by Mark I. Wallace, translated by David Pellauer (Minneapolis: Fortress Press, 1995), 37.
} 
he says, "that grammatical codes have a generative function, to help generate discourse as a sentence, the literary codes too have a generative function. They serve to generate function as a narrative, a proverb, and so forth."11 Like Ricoeur, what I mean by genres of expression also has a generative and productive function. Unlike Ricoeur, it goes further than just the production of discourse as written text. I want to signal the production and expression of knowledge and truth claims as written texts but also as film, as visual and performance arts, as music, sound, and lyrics. Ricoeur's modes of discourse, then, are a subset of what I mean by genres of expression.

The final notion needed to preface sonic-apologetics is the distinction between linear and angled apologetic responses. The ability to respond to counter-Christian knowledge from an angle is a significant advantage for Christian apologetics. What do I mean? Apologetics frequently locks itself into a thesis-antithesis mode. An atheist, for example, says $\mathrm{P}$ and we Christians say not $\mathrm{P}$, or vice-versa. Muslims say not $\mathrm{Q}$ but we Christians believe Q. Scientific materialism implies not $\mathrm{Y}$ and not $\mathrm{Z}$, but the Gospel maintains both $\mathrm{Y}$ and $\mathrm{Z}$. This is to respond to the content of anti-Christian knowledge and truth claims linearly. Its aim is to directly assert or deny the opposite of what Christianity's critics assert or deny. To do so, an apologist will use the same genre of expression the counter-Christian knowledge claim is expressed in. If the New Atheist writes in prose so will the Christian apologist. If the Muslim criticizes Christianity in fictional literature, the apologist will respond in fictional literature. This is fighting fire with fire; going head-to-head with anti-Christian claims.

Linear apologetic responses are no doubt useful on many fronts. They are necessary when clarifying the content of Christianity and distinguishing it from other worldviews. Moreover, it is often a first step in polemics too.

$11 \quad$ Ibid., 38. 
However, this approach neglects the enunciation and effects of the production of counter-Christian knowledges in favor of their content. Shifting our attention to the geopolitics of counter-Christian knowledge production enables apologetics to give angled responses. There are two dimensions to angled responses. The first is not producing and pursuing linear responses. When a New Atheist asserts that $\sim \mathrm{P}$ "there is no God," instead of responding by arguing that $\mathrm{P}$ "there is a God" we would argue for a claim Q "Jesus is Love," whose effects would counter the effects of $\sim$ P. The effects of $\sim P$ are obviously to criticize Christianity and separate people from God. This is a battle of effects. By asserting $\mathrm{Q}$, that Jesus is Love, against $\sim \mathrm{P}$, that there is no God, we are countering the effects of what the Atheist antiChristian claim intends to produce. Attending to effects of enunciation allows apologetics to make these kinds of strategic moves.

The second dimension of angled apologetic responses concerns strategically switching genres of expression. Rather than asserting that $\mathrm{P}$ "Jesus is God" in textbook prose as a response to an Atheist or Muslim asserting P "Jesus is not God" in textbook prose, we would produce and polemically launch $\mathrm{P}$ as knowledge expressed in a fictional novel or film, drama or poem. We would perform or sing that P "Jesus is God" as an apologetic response to Atheists or Muslims asserting that $\sim \mathrm{P}$ in textbook prose. An angled response strategically harnesses the numerous different possible effects across the spectrum of different genres of expression in order to counter the effects of a particular anti-Christian knowledge or truth claim. We use, for instance, the effects and influence produced by poetry, song and film to battle the effects of an anti-Christian knowledge claim articulated in prose, for instance. This is to harness the effects across several genres of expression in our apologetic responses. Here, we fight fire with water, earth and air.

That apologetics has not been angled; that it has been fixed in a linear mode; that it has not methodologically attended to effects of enunciation has 
been a major impediment to both democratizing apologetics and making sonic-apologetics possible. Christian musicians simply do not think it possible to respond to a Richard Dawkins, Sam Harris or Christopher Hitchens on any level. The New Atheists occupy one genre of expression and the worship leaders a wholly disparate other. No contact can be made between the worship, lyrics, music and sound of the latter with the atheistic science and philosophical writings of the former. This assumes a linear view of apologetics, where if a critical Muslim writes in philosophical prose Christian apologists must respond in philosophical prose. If the former asserts $\sim \mathrm{P}$ "Jesus is not God" the latter can only deny it and argue that $\mathrm{P}$ "Jesus is God." Worship leaders and musicians might not have what it takes to do this, nor may they know how, so they leave apologetics to those with the appropriate training in philosophy, theology, science and the relevant genres of expression.

To turn this deleterious tide, if we combine the first two necessary notions we get the following: anti-Christian music functions like well-formed, rational arguments posed by Christianity's critics. The former operate in one genre of expression (the musical) and the latter in another (philosophical prose). Both intend to produce the same effect - to edge the audience away from God - but through different means. If we add the third necessary notion we see that both the anti-Christian music-makers and the antiChristian intellectuals are assaulting Christianity from two different angles. We can also now see how an anti-Christian song constitutes a musical criticism of certain Christian theistic texts. For example, Hozier in musically criticizing Calvin's notion of total depravity might as well be responding to sections of his Institutes. Similarly, Drake's notion that "you only live once" might as well be a critical response to biblical references to heaven and a morally accountable eternal soul. These three concepts collectively respond to the five problems we began with. They make sonic-apologetics possible, which harnesses the power of music for apologetic purposes, and therefore 
begins to democratize apologetics since it is tailored to the native interests and abilities of music-makers. It enables us to see musical criticisms of the Gospel as musical criticisms and allows us to respond accordingly to more apologetic threats than we hitherto have.

These three notions provide the framework wherein sonic-apologetics can now be described. Sonic-apologetics is the name I give to the distinctive kind of apologetics Christian music-makers are already uniquely talented and trained to engage in. It harnesses the persuasive power of music to counteract the effects of critical anti-Christian claims from an angle. It launches one unique genre of expression and its effects against those in which criticisms of Christianity are asserted. In doing so, it demonstrates the value and power of music as a unique resource for Christian apologetics. The task of a sonic-apologist is to engineer music whose effects defend the Gospel, edge people closer to Christ and Christ closer to culture. Sonicapologetics harnesses the unparalleled power of music to impact various levels of society for the Gospel. It makes music that communicates Reformed truth but also defends this truth against all criticism of it; philosophical, theological, and scientific but also musical ones as well.

\section{Two Cases of Sonic-Apologetics}

The task of a sonic-apologist is to make music whose effects defend the gospel of Jesus Christ from existing criticisms of it. This means they need to have a general idea of how and what kinds of criticisms are being launched against Christianity. They do not need to know philosophy, theology, science or literature in depth in order to do this, provided that they have a general idea of what the critics of Christianity are saying or they work with someone who does. The traditional apologist, then, can ally with and work side-by-side with Christian music-makers (sonic-apologists). 
Amanda Cook, from the contemporary worship band Bethel, offers a clear case of sonic-apologetics with her 2015 song titled "Kind." First, however, consider the following three arguments and sentiments produced to critique Christianity.

1. God is (like) a divine dictator. The late Christopher Hitchens, one of the "Four Horsemen" of the New Atheism, was fond of referring to God in this way, especially in his debates. Commenting on the alleged violence in the Old Testament, he says in his 2007 God Is Not Great, "This is forgivable in the part of the provincial yokels, obviously, but what then of their supreme guide and wrathful tyrant? Perhaps he was made in their image, even if not graven?"12 The argument here is that the God Christians and Jews worship is like a divine and omnipotent "wrathful tyrant" who delights in the arbitrary suffering, pain and oppression of his creatures.

2. Christian morality is motivated by fear of punishment or hell. It is sometimes thought that the main or only reason Christians try to be good Christians and overall moral people is because they are afraid that doing otherwise would condemn them to hell or other kinds of punishment by God. It is fear of punishment that motivates our Christian moral desires and behaviors, in other words. This view is motivated, amongst other things, by thinking of God, as Freud suggests, like "an enormously exalted father." Punishment is the result of not doing what our fathers say. In like manner, for Freud, punishment from God is the motivating engine behind behaving morally and doing what He says. This, for him, "is so patently infantile, so foreign to reality."13 UK-based ex-Christian

\footnotetext{
12 Christopher Hitchens, "Revelation: The Nightmare of the 'Old' Testament" in God Is Not Great: How Religion Poisons Everything (New York, NY: Twelve Hackett Book Group, 2007), 108. 13 Sigmund Freud, Civilization and Its Discontents, translated by James Strachey (New York: W.W. Norton \& Company, 2010), 39.
} 
rapper, Jahaziel publically denounced the faith for similar reasons. "You can believe the Bible and its God all you want," he says, "but to me he just demands my fear ... my conclusion is that Christianity (its flawed book, bloodthirsty god and mythical savior) I have found unsatisfactory and unworthy of my allegiance or worship unless by threatening to kill me if I don't - as Christianity does." ${ }^{14}$ Here too, threat of punishment from God is thought to be the motivating factor behind Christianity and its morality.

3. Religion, especially Christianity, is an ideological instrument used to keep people in conformity with the status quo. It is a mechanism used to serve the agendas of certain sociopolitical powers and interests. In Marx's case, religion is "the opium of the people" that serves capitalism. ${ }^{15}$ Interestingly, religion also functions as an opium of the masses in Aldous Huxley's 1932 Brave New World, a dystopian novel about a future London society where social stability and advanced science and technology drown out individuality and autonomy. ${ }^{16}$ In the novel, there is a drug called soma that anyone can take to make him or her immediately happy and virtuous. It gives its users a "holiday from the facts." Essentially, the soma drug is "Christianity without tears." ${ }^{17}$ It is used to sedate society into conformity with the World State's mission and motto of "Community, Identity, Stability." In both Marx and Huxley, religion, particularly Christianity, functions to prevent any revolutionary challenges to a particular sociopolitical power and order.

\footnotetext{
14 See http://www.charismanews.com/culture/54193-christian-rapper-renounces-his-faith-injesus-as-great-falling-away-continues

15 Karl Marx, "Toward a Critique of Hegel's Philosophy of Right: Introduction" in Selected Writings, edited by Lawrence H. Simon (Indianapolis: Hackett, 1994), 28.

16 Aldous Huxley was the grandson of Henry Huxley, the famed $19^{\text {th }}$ century biologist known as “Darwin's Bulldog."

17 Aldous Huxley, Brave New World (New York, NY: Harper Perennial Modern Classics, 1932), 235-38
} 
In both cases, religion acts against our real interests and simultaneously blinds us about what these real interests are.

The sentiments and arguments expressed in (1)-(3) are clearly meant to critique religion and especially Reformed theology. They attempt to persuade people away from Christ and build barriers against the Gospel. It is imperative to observe how in them various genres of expression are used to assert anti-Christian claims. In all this, Christianity is being criticized from various angles, from different genres of expression. These variously expressed arguments have gained some cultural momentum and produced common resistance to religion in general and Reformed theology in particular. Christian apologists, of course, are expected to respond.

It is here where I would like to consider Amanda Cook and her worship team Bethel as sonic-apologists engaged in producing an angled apologetic response to (1)-(3) with her song called "Kind" in her 2015 album titled Brave New World. Here are the lyrics. ${ }^{18}$

\section{Verse 1}

You are not a tyrant King

You do not delight in suffering

Your power doesn't compensate for insecurity

'Cause You are not a tyrant King

Verse 2

You are not an angry man

You do not treat us with contempt

Your voice is sure, Your eyes are soft, Your smile, confident

'Cause You are not an angry man

18 For a YouTube video of the song with lyrics see: https://youtu.be/e9dP8IvGUEo. 
Chorus

You are kind $(\mathrm{x} 4)$

Verse 3

Your love is a fury all its own

Sweeping the dust and turning feet towards home

Carrying the orphans and resetting broken bones

Your love is a fury all its own

Bridge

And love is powerful enough

Without the fear of punishment ${ }^{19}$

This is what sonic-apologetics looks like. It is a powerful angled apologetic response to Hitchens, Freud, Jahaziel, Marx, Huxley, and other cultural despisers of religion. The entire first two verses destabilize Hitchens' suggestion that God is like a divine dictator. God is not a tyrant King. God does not delight in arbitrary suffering. He is not like an angry man who treats us with contempt. He is kind.

The third verse and the chorus undo the anti-Christian notion that fear motivates Christianity and its morality. It is not the fire of hell that moves us but the fury of God's love. His love is powerful enough. Against (2), Cook sings that Christians aspire to holiness and goodness without the fear of punishment.

In light of (3), is it a coincidence that the name Cook gives to her album, Brave New World, is identical to the title of Huxley's novel? No. Her point is that far from being an "opium of the masses," far from being a selfserving instrument of sociopolitical powers and interests, God's furious love is what truly liberates us. Rather than ideologically blinding us about our

19 See https://bethelmusic.com/albums/brave-new-world/ 
real interests, God reveals them as they are and satisfies them over abundantly. Cook's song asserts that Christianity is the real Brave New World, not the stuff Huxley peddled. In fact, her prayer for the album is, as she puts it, "that you would experience the reality that you, in fact, house a Brave New World; you are a Brave New World. May you be filled with hope in the One whose mercy is timeless, and whose Love for mankind is as boundless as the sea." 20

This song harnesses the power of contemporary worship music to give an angled apologetic response to (1)-(3). The effects the song produces battles the effects and influence produced by anti-Christian claims. It launches the musical genre of expression against the philosophical prose of Hitchens, Freud, and Marx, the fiction of Huxley and the coming antiChristian rap of Jahaziel. Cook explains that her album is founded on the knowledge that "God has been on our side all along and that He has given us permission to wrestle with truth, process pain, and ask big questions." 21 The album is her doing just that. And isn't wrestling with truth and asking big questions what apologetics is all about? Of course, it is. That is why with Bethel and Amanda Cook's album Brave New World, especially the song "Kind," we have a paradigm of sonic-apologetics.

Another case of sonic-apologetics is Michael Tait's 2011 song “God's Not Dead." Tait is the lead vocalist of the contemporary Christian pop rock band Newsboys. They use the power of pop rock music to give an angled apologetic response to folks like Friedrich Nietzsche, the self-proclaimed "anti-Christ."

Nietzsche was responsible for popularizing the phrase "God is dead" in the 19th century. In his 1882 The Gay Science, Nietzsche tells his famous "Parable of the Madman," where he announces that "God is dead. He

\footnotetext{
20 Ibid.
}

21 Ibid. 
remains dead. And we have killed him." ${ }^{22}$ The theme of God's death also repeatedly emerges in his 1883 Thus Spoke Zarathustra: "Could it then be possible! This old saint in his forest has not yet heard of it, that God is dead!"23 What the death of God precisely means and implies for Nietzsche is a highly complex and debated issue. At the very least, however, it suggests not only that God does not exist but also that God makes no significant difference in our modern lives. Nietzsche's point is that God is irrelevant.

Tait and the Newsboys produce an angled apologetic response to Nietzsche. Here is the chorus of Tait's song.
My God's not dead
$H e^{\prime}$ s surely alive
He's living on the inside
Roaring like a lion

This is what sonic-apologetics sounds like. The Newsboys use a musical genre of expression to deny what Nietzsche asserts through his philosophical prose. The song is designed so that its effects respond to and reverse the effects of Nietzsche's texts, which is to edge people away from Christianity. Sonic-apologists engineer and design songs like these with objectives like these in mind, namely to combat the effects criticisms of Christianity intend to produce.

\footnotetext{
22 Friedrich Wilhelm Nietzsche, "Book 3, Section 125" in The Gay Science: With a Prelude in Rhymes and an Appendix of Songs, translated by Walter Arnold Kaufmann (New York: Vintage Books [1882], 1974), 181-82.

23 Friedrich Wilhelm Nietzsche, "Zarathustra's Prologue" in Thus Spoke Zarathustra, translated by Clancy Martin (New York: Barnes \& Noble Classics), 9.
} 


\section{Conclusion}

In this essay, I delineated five challenges to which sonic-apologetics is a response. I analyzed and illustrated how Christianity is being musically critiqued. Then, I introduced three notions that are necessary for constructing sonic-apologetics, after which I presented two cases of sonicapologetics. It has been my concern in this essay only to introduce sonicapologetics as a much-needed possibility for the Church. Because of space limitations, I have not defended it from the many questions and theological concerns I know are out there. The only thing I will say in this regard is that if we are serious about impacting societies we must be willing to speak their language and use their genres of expression. We cannot afford to let the secular world hijack the power of music and monopolize its power for ungodly purposes. We cannot shy away from using the genres of music that most speaks to people in society. Genres of music are going to function in culture, for or against God, whether or not the Church decides to use these genres. The cultural despisers of Christianity will continue to pen lyrics that lacerate Christian views and values. It is up to our music-makers to articulate Reformed theology and defend its truth through musical genres of expression. It is up to them to produce angled apologetic responses to criticism of Christianity in culture, breaking down barriers to the Gospel. Sonic-apologetics makes this possible. It allows the Church to aim its musicmaking power outward to influence culture. In doing so, it prepares Reformed theology to impact contemporary and future societies as much as possible. None of this requires changing the Church's liturgy. It does require Christian music-makers to take on the mantle of apologetics, perhaps for the first time. 